\title{
Nominal classification in Asheninka (Arawak)
}

\section{Elena Mihas}

University of Wisconsin-Milwaukee

elmihas@uwm.edu

\section{Introduction ${ }^{1}$}

This account of Ashéninka classifying morphemes investigates the following: 1) What are the systems of nominal classification in Ashéninka Perené? 2) Where do they come from? 3) Do they overlap? 4) How do the study's findings contribute to the typology of nominal classification in Kampan languages and general typology of classifying systems? The Ashéninka Perené types of classifying morphemes are examined from a diachronic perspective, conceived as a continuum of classifying systems arranged along a grammaticalization axis which places classifiers at a mid-point between the lexical systems of classification and grammatical systems of noun/gender classes (Grinevald 2000:61). The Ashéninka Perené case provides intriguing evidence of the existence in one language of all three classification types.

\section{Ashéninka Perené lexical systems of nominal classification: class and measure terms ${ }^{2}$}

Measure terms in Ashéninka Perené include -poroki 'bunch', -patsa 'dot, tiny piece', -kota 'piece', and-vatsa 'mass'. The productive measure terms - poroki 'bunch' and -patsa 'tiny piece, dot' are used in the quantification of count nouns while marginally productive -kota 'piece' and -vatsa 'mass' can be used in the unitizing of mass nouns. The measure terms are summarized in (1).

\begin{tabular}{|l|l|l|l|l|}
\hline & Measure term & Gloss & Function & Example \\
\hline (1a) & - poroki & bunch & to quantify count nouns & mapi-poroki 'a bunch of stones' \\
\hline (1b) & - patsa & tiny piece & to quantify count nouns & kaniri-patsa 'a tiny piece of manioc' \\
\hline (1c) & - kota & piece & to unitize mass nouns & ashiro-kota 'a piece of iron' \\
\hline (1d) & - vatsa & mass & to unitize mass nouns & kaniri-vatsa 'manioc mass' \\
\hline
\end{tabular}

Ashéninka Perené has a comprehensive list of class terms, as seen in (2).

\begin{tabular}{|l|l|l|l|l|}
\hline No & Class term & Gloss & Origin & Example \\
\hline & & & & INANIMATE \\
\hline$(2 \mathrm{a})$ & - tonki & long segment & bone & incha-tonki 'wood beam' \\
\hline$(2 \mathrm{~b})$ & - panki- & plank & plant & incha-panki 'wood plank [split wood]' \\
\hline$(2 \mathrm{c})$ & - tyaki & flower & blossom & incha-tyaki 'flower' \\
\hline
\end{tabular}

\footnotetext{
${ }^{1}$ The material presented in this study is based upon field work in the communities of Pampa Michi and Bajo Marankiari, Junin Province, Peru, supported by the National Science Foundation under Grant No.BCS-0901196.

${ }^{2}$ The abbreviations used:1-first person, 3-thrid person, A-subject of transitive verb, ADV-adverbial, CL-classifier, DIR-directional, DISTR-distributive, DUR-durative, EP-epenthetic, IMP.P-impersonal passive, IRR-irrealis, LOClocative, m-masculine, LOC.DEM-locative-demonstrative, n.m-non-masculine, O-object, PRF-perfective, PROGprogressive, REAL-realis, REGR-regressive, S-subject of intransitive verb, SUBJ-subjunctive.

${ }^{3}$ The practical orthography used in this paper corresponds to the following phonemic values: $\left.<\mathrm{i}>/ \mathrm{i} /,<\mathrm{e}\right\rangle / \mathrm{e} /,<_{0}>$ /o/, < a $>/ \mathrm{a} /,<\mathrm{ii}>/ \mathrm{i}: /,<\mathrm{ee}>/ \mathrm{e}: /,<\mathrm{oo}>/ \mathrm{o}: /,<\mathrm{aa}>/ \mathrm{a}: /,<\mathrm{p}>/ \mathrm{p} /,<\mathrm{py}>/ \mathrm{p}^{\mathrm{j}} /,<\mathrm{k}>/ \mathrm{k} /,<\mathrm{ky}>/ \mathrm{k}^{\mathrm{j}} /,<\mathrm{t}>/ \mathrm{t} /,<\mathrm{ty}>/ \mathrm{t}^{\mathrm{j}} /,<\mathrm{tz}>/ \mathrm{ts}^{\mathrm{h}} /$, $<\mathrm{ts}>/ \mathrm{ts} /,<\mathrm{ch}>/ \mathrm{tg} /,<\mathrm{s}>/ \mathrm{s} /,<\mathrm{sh}>/ \mathrm{g} /,<\mathrm{h}>/ \mathrm{h} /,<\mathrm{m}>/ \mathrm{m} /,<\mathrm{n}>/ \mathrm{n} /,<\mathrm{ny}>/ \mathrm{n} /,<\mathrm{r}>/ \mathrm{f} /,<\mathrm{ry}>/ \mathrm{s}^{\mathrm{j}} /,<\mathrm{v}>/ \mathrm{w} /,<\mathrm{y}>/ \mathrm{j} /$.
} 


\begin{tabular}{|l|l|l|l|l|}
\hline$(2 \mathrm{~d})$ & $-t o$ & tree, trunk & unknown & incha-to 'tree' \\
\hline$(2 \mathrm{e})$ & $-s h i$ & leaf & leaf & inchato-shi 'tree leaf' \\
\hline$(2 \mathrm{f})$ & $-k i$ & seed, fruit & unknown & incha-ki 'fruit, seed' \\
\hline$(2 \mathrm{~g})$ & $-k i i$ & stick & unknown & incha-kii 'stick' \\
\hline$(2 \mathrm{~h})$ & - chee & thorn, spine & thorn, spine & savoro-chee 'giant cane thorn' \\
\hline$(2 \mathrm{i})$ & $-p a$ & banana & unknown & katzimaro-pa 'banana species' \\
\hline$(2 \mathrm{j})$ & $-v e n k i$ & magic plant & plant species & $\begin{array}{l}\text { masonto-venki 'plant that helps } \\
\text { hypnotize the enemy' }\end{array}$ \\
\hline$(2 \mathrm{k})$ & $-v a t s a$ & meat & meat, flesh & tontori-vatsa 'meat of porcupine' \\
\hline & & & & ANIMATE \\
\hline$(2 \mathrm{l})$ & $-n k i$ & snake & snake & noo-nki 'boa anaconda' \\
\hline$(2 \mathrm{~m})$ & $-s a n i$ & wasp & wasp & keni-sani 'yellow-legged wasp' \\
\hline$(2 \mathrm{n})$ & $-k e n i$ & worm & worm & poro-keni 'soapberry worm' \\
\hline$(2 \mathrm{o})$ & $-k i$ & social insect & unknown & kakai-ki 'coffee plant ant species' \\
\hline$(2 \mathrm{p})$ & $-n a r i$ & wild & unknown & kipatsi-nari 'wasp species' \\
\hline & & & & HUMAN \\
\hline$(2 \mathrm{q})$ & $-t s o r i$ & distant kinship & unknown & noniro-tsori 'maternal aunt' \\
\hline$(2 \mathrm{r})$ & $-n i$ & dead & unknown & nochoki-ni 'my dead sister' \\
\hline$(2 \mathrm{~s})$ & - satsi & provenance & unknown & katonko-satsi 'from upriver' \\
\hline
\end{tabular}

The class terms in (2) derive from generic nouns and express their classifying function by compounding or derivational morphology. In classifying compounds, the first element of the compound is a variable $\mathrm{X}$ and the second element is a stable morpheme $\mathrm{Y}$ of a clear lexical origin). The reduced class terms ( $2 \mathrm{~d}-\mathrm{i}, 1, \mathrm{o}-\mathrm{s})$ are used as nominal derivational suffixes. They appear to be more grammaticalized as they have lost an ability to be used as single forms and their lexical origin may not be accessible. The semantic motivation for a sizable number of the vegetal and animal class terms is evidently to organize the physical world with which the speakers interact on a daily basis and obtain detailed information about the jungle environment. The plant-based terms in (2) have a limited productivity with both native and newly introduced cultural items. Most of the class terms appear to be lexicalized as parts of original compounds which have become frozen in time. The more productive classifying morphemes - $p a$ 'banana fruit', $-s h i$ 'leaf' and $-k i$ 'fruit, seed' have been found to have broader semantics while the rest of the class terms seem to have retained their basic meanings.

\section{Ashéninka Perené classifier system: noun and verbal classifiers}

Our fieldwork data show that there are noun and verbal classifiers in Ashéninka Perené. The set of morphemes used as noun classifiers in Asheninka Perené is given in (3), followed by examples in (4).

\begin{tabular}{|l|l|l|l|l|}
\hline & Classifier & Semantics & Origin & Examples \\
\hline (3a) & $-n a$ & long, hollow & unknown & holes, burrows, bones \\
\hline (3b) & $-n a k i$ & round, hollow & unknown & clay pots, lamps \\
\hline (3c) & $-t s a$ & long, thin, flexible & $-t s a$ 'liana, rope' & lianas, ropes, roots, hair \\
\hline (3d) & $-p i$ & rigid, hollow & $-p i$ 'hollow stalk' & arrows, reed, needles \\
\hline
\end{tabular}




\begin{tabular}{|l|l|l|l|l|}
\hline$(3 \mathrm{e})$ & $-s h i$ & small, thin, flexible & $-s h i$ 'leaf' & herbs, grass, garbage \\
\hline$(3 \mathrm{f})$ & $-k i$ & small, round; hard & unknown & coffee beans, pits, beads; trees \\
\hline$(3 \mathrm{~g})$ & $-p a$ & cylindrical, pod-like & $-p a$ 'fruit pods' & pod-like fruit \\
\hline
\end{tabular}

\begin{tabular}{|l|l|l|}
\hline (4a) & $-n a$ 'long, hollow' & \\
\hline & $n o=v e t s i k-a-y e-t-a v-a k-e=t a$ & omoro- $n a$ \\
\hline & $1 \mathrm{~S}=$ make-EP-DISTR-EP-DIR-PRF-IRR=SUBJ & hole-CL: long. hollow \\
\hline & 'I'll prepare each hole for the trees.' & \\
\hline$(4 \mathrm{~b})$ & $-n a k i$ 'round, hollow' & \\
\hline & $i=k a n t-a i-t z i=r o$ & kipatsi-naki \\
\hline & 3 m.A=call-IMP.P-REAL=3n.m.O & land-CL:round. hollow \\
\hline & 'It's called the moon.' & \\
\hline
\end{tabular}

In (4), the noun classifiers are bound forms directly marking the nominal stem. They occur freely in ordinary noun phrases, without being restricted to quantification or possession contexts. They cannot be used anaphorically. The classifiers in (4) specify nouns according to their shape/dimensionality and consistency, performing a derivational function. The noun classifiers can be used with animate and inanimate nouns, with both native and recently introduced cultural items. At least some of Ashéninka noun classifiers are derived from class terms. Originally denoting plant parts, they have developed broader semantics e.g. -shi 'leaf'; 'small, flat, flexible thing', - $k i$ 'seed', 'fruit'; 'small, round or hard thing', and - $p a$ 'banana fruit'; 'cylindrical, podlike thing'.

Verbal classifiers, found inside the verb form, classify the nominal argument of the verb. Ashéninka Perené verbal classifiers - ako 'vessel', -poroki 'bunch', and - $k i$ 'small, round' are reduced forms whose original meanings are obscure. A list of Ashéninka Perené verbal classifiers is given in (5), followed by examples in (6).

\begin{tabular}{|l|l|l|l|}
\hline (5) & Classifier & Semantics & Examples \\
\hline & $-a k o$ & vessel & pots, recipients of any kind \\
\hline & $-p o r o k i$ & bunch & any count noun (human, animate or inanimate) \\
\hline & $-k i$ & small, round & beads, seeds, beans \\
\hline
\end{tabular}

\begin{tabular}{|l|l|l|}
\hline (6a) & osheki & $y=$ ashit-a-poroki-vai-tzi \\
\hline & many & 3m.S=get.wet-EP-CL:bunch-DUR-REAL \\
\hline & 'Many [handicrafts] get wet.' \\
\hline (6b) & hiri & $i=$ saik- $a$-poroki-tzi=ra \\
\hline & LOC.DEM & 3m.S=sit.on-EP-CL:bunch-REAL=ADV \\
\hline & 'He is sitting, a bag of bones, over there.' \\
\hline (6c) & $a=t$ sipa-poroki- $t$-ak- $e=r o$ \\
\hline & 1PL.A=combine-CL:bunch-EP-PRF-REAL=3n.m.O \\
\hline & 'We combine some of them [words].' \\
\hline (6d) & noina & $o=n=k o y e-k i-t$-ah-aty-e \\
\hline & my.wife & 3n.m.S=IRR-gather-CL:small.round-EP-REGR-PROG-IRR \\
\hline & 'My wife will be gathering coffee beans.' \\
\hline
\end{tabular}




\begin{tabular}{|l|l|l|l|}
\hline$(6 \mathrm{e})$ & apata, & incha-kota- $k i$, & $y=$ apishoink-ako-it-ak-i=na=ro \\
& wait & plant-piece-LOC & $\begin{array}{l}3 \mathrm{~m} . \mathrm{A}=\text { throw-CL:vessel-partially-PRF- } \\
\text { REAL=1O=3n.m.O }\end{array}$ \\
\hline & & & \\
\hline
\end{tabular}

Verbal classifiers in (6) are used without an overt referent NP and/or cross-referencing marking and refer to $\mathrm{S} / \mathrm{O}$ and $\mathrm{Obl}$ arguments of the verb. Their semantics includes categories of quantity, arrangement, and shape/dimensionality. The origin of Ashéninka Perené verbal classifiers is difficult to pinpoint. Arguably, body parts serve as the most frequent source of verbal classifiers, found in the grammaticalized constructions with body part incorporation (Aikhenvald 2000:355). The verbal classifiers could have been the result of cross-pollinating grammaticalization processes when the lexical forms, the incorporated inalienable noun and the measure/class term (and the noun classifier, in the case of the verbal classifier $-k i$ ) served as its source.

\section{Gender-based nominal classification in Ashéninka Perené}

Data indicate that Ashéninka nouns take agreements as they are given in (7).

\begin{tabular}{|l|l|l|l|l|l|l|l|}
\hline (7) & Gender & Adjective & Demonstrative & Personal pronoun & Possessive pronoun & Predicate & Adverb \\
\hline & Masc & $-r i$ & $($ i $r i-/($ i $)$ yo- & iri- & ir- & i-/y-; $-r i$ & hiri- \\
\hline & Non-m & - ro & iro- & iro- & $\varnothing-$ & o-; - ro & hiro- \\
\hline
\end{tabular}

The complex gender-based classification system in (7) is extensively grammaticalized, with alliterative agreeing morphemes on various elements of the clause that resemble gender markers on the noun controllers. The gender assignment system is predominantly based on semantic grounds. Nouns denoting human males are singled out as masculine and all the rest are nonmasculine by default, with a number of exceptions. The masculine gender includes male rationals, denoting human males and various mythical beings. Our data indicate that the personal pronouns iri(ro) 'he' and iroo 'she' have served as the source of the language's gender assignment rules.

\section{Conclusions}

The classification system of Ashéninka Perené includes class and measure terms, noun and verbal classifiers, and a gender system, showing that three systems of nominal classification can co-exist in one language. Ashéninka Perené lacks a 'multiple' classifier system, characteristic of some Kampan and other Amazonian languages since its inventories and functions of the noun and verbal classifiers, essentially, do not overlap. There is evidence that at least some of Ashéninka Perené classifiers such as $-s h i$ 'small, flexible, thin', - $k i$ 'small, round; hard', $-p a$ 'cylindrical, pod-like' have evolved from their counterpart class terms. The emergence of the Ashéninka Perené gender system is not linked to its classifiers. Its gender markers $(r) i /(r) o$ go back to the personal pronouns, a grammaticalization cline attested in Kampan and other Arawak languages (Aikhenvald 2000:368).

\section{References}

Aikhenvald, Alexandra. 2000. Classifiers: A Typology of Noun Categorization Devices. Oxford: Oxford University Press.

Grinevald, Colette. 2000. A morphosyntactic typology of classifiers. Systems of Nominal Classification, ed. by Gunter Senft, 50-92. Cambridge: Cambridge University Press. 